\title{
Regulation of Human Monocyte/Macrophage Function by Extracellular Matrix \\ Adherence of Monocytes to Collagen Matrices Enhances Phagocytosis of Opsonized Bacteria by Activation of Complement Receptors and Enhancement of Fc Receptor Function
}

Simon L. Newman and Michelle A. Tucci

Division of Infectious Diseases, Department of Internal Medicine, University of Cincinnati Medical Center, Cincinnati, Ohio 45267

\begin{abstract}
In inflammation monocytes emigrate from the peripheral circulation into an extravascular area rich in extracellular matrix proteins. In this milieu, phagocytes ingest and kill invading pathogens. In the present studies, we found that monocytes adhered to type I collagen gels phagocytized 2.5-12-fold more opsonized Escherichia coli, Staphylococcus aureus, Streptococcus pyogenes, and Streptococcus pneumoniae than plasticadherent monocytes. The rate of phagocytosis and the number of bacteria ingested by collagen-adherent monocytes was equal to, or greater than, the number of bacteria ingested by 7-d cultured macrophages (M $\phi)$. Although both collagen- and plastic-adherent monocytes were bactericidal for $E$. coli and $S$. aureus, more bacteria were killed by collagen-adherent monocytes by virtue of their enhanced phagocytic capacity. Cultured M $\phi$ only were bacteriostatic.

Adherence of monocytes to collagen gels activated $\mathrm{C}$ receptors (CR) types 1 and 3 for phagocytosis, and enhanced Fc receptor (FCR)-mediated phagocytosis. Collagen- and plasticadherent monocytes produced equivalent amounts of superoxide anion in response to phorbol myristate acetate and opsonized zymosan. Thus, the enhanced phagocytosis and killing of opsonized bacteria by collagen-adherent monocytes appear to be by regulation of the function of membrane $C R$ and $F c R$, without apparent enhancement of the respiratory burst. These data suggest that adherence of monocytes to the extracellular matrix during inflammation may rapidly activate these cells for enhanced phagocytic bactericidal activity. (J. Clin. Invest. 1990. 86:703-714.) Key words: collagen - monocyte • macrophage $\bullet$ complement receptors $\bullet$ phagocytosis $\bullet$ Fc receptors
\end{abstract}

\section{Introduction}

Gram-positive and gram-negative pathogenic bacteria require opsonization by serum proteins to be recognized, phagocytized, and killed by "professional" phagocytes (neutrophils,

Address reprint requests to Dr. Newman, Division of Infectious Diseases, University of Cincinnati College of Medicine, Cincinnati, OH 45267.

Received for publication 22 September 1989 and in revised form 4 April 1990

1. Abbreviations used in this paper: $\mathrm{BAP}$, blood agar plate; $\mathrm{CR}$, complement receptor; E, sheep erythrocyte(s); FcR, Fc receptor; HBSA, Hanks'-Hepes buffer containing $0.25 \%$ BSA; $M \phi$, macrophage(s); PHS, pooled human serum; PI, phagocytic index; VLA, "very late antigen(s)."

J. Clin. Invest.

(c) The American Society for Clinical Investigation, Inc. 0021-9738/90/09/0703/12 \$2.00

Volume 86, September 1990, 703-714 monocytes, and macrophages $[\mathrm{M} \phi])^{1}(1-3)$. Initiation of the inflammatory response by these microbes activates the complement $(\mathrm{C})$ system, and the serum opsonins $\mathrm{C} 3 \mathrm{~b}$, iC $3 \mathrm{~b}$, and IgG become bound to the microbial surface (4-10). The specific plasma membrane receptors to which these ligand-coated bacteria bind, $C$ receptor $(C R)$ type $1\left(C_{1}\right)(11), C R$ type 3 $\left(C_{3}\right)(12,13)$, and $F c$ receptors $(F c R)(14)$, respectively, have been identified and structurally characterized. The importance of these opsonins and receptors in host defense is illustrated by the fact that individuals with genetic deficiencies of $\mathrm{C} 3$ (15), IgG (16), or $\mathrm{CR}_{3}$ (17) suffer recurrent life-threatening infections.

In vitro studies have shown that phagocytosis via $F c R$ is a constitutive property of phagocytes and that CR-mediated phagocytosis is developmentally regulated (18-24). Thus, binding of $\mathrm{C} 3 \mathrm{~b}$ - or $\mathrm{iC} 3 \mathrm{~b}$-coated particles to human neutrophils (PMN) (18-20) or monocytes (21-23) is not followed by ingestion, whereas IgG-coated particles always are ingested (18-23). CR may be activated for phagocytosis by several agents including phorbol esters $(23,25)$, cytokines (26), and extracellular matrix proteins (27-31). These agents also may enhance FcR-mediated phagocytosis $(25,28,29,31-33)$.

Type I collagen is the most abundant of the fiber forming collagens, and is the major collagen of skin, tendon, bone, and other tissues. Culture of monocytes on type I collagen for $72 \mathrm{~h}$ has been shown to induce the production of $\mathrm{PGE}_{2}$ and IL-1 (34), and tumor necrosis factor- $\alpha$ (TNF $\alpha$ ) mRNA was expressed as early as $4 \mathrm{~h}$ after adherence of monocytes to collagen (35). Monocytes cultured on collagen rather than glass phenotypically resemble resident tissue $\mathbf{M} \phi$ and are not cytotoxic (36). In addition, monocytes cultured on collagen gels for $48 \mathrm{~h}$ exhibited CR-mediated phagocytosis and enhanced FcR-mediated phagocytosis compared with monocytes cultured on glass (27).

In the present experiments, the phagocytic and bactericidal activity of monocytes adhered to type I collagen gels was quantified and compared with the phagocytic and bactericidal activity of plastic-adherent monocytes and 7-d adherently cultured $\mathrm{M} \phi$. The data show that the rate of phagocytosis and the number of opsonized bacteria phagocytosed by collagen-adherent monocytes was severalfold greater than the phagocytic capacity of plastic-adherent monocytes, and similar to the phagocytic capacity of 7-d cultured $\mathbf{M} \phi$. Collagen- and plastic-adherent monocytes mediated significant bactericidal activity for opsonized Escherichia coli and Staphylococcus aureus, but more bacteria were killed by collagen-adherent monocytes by virtue of their increased phagocytic capacity. Cultured M $\phi$ only were bacteriostatic. The enhanced phagocytic bactericidal activity of collagen-adherent monocytes appeared to be mediated by activation of $C R_{1}$ and $C R_{3}$ for phagocytosis, and enhancement of FcR-mediated phagocytosis, without apparent enhancement of the respiratory burst. 


\section{Methods}

\section{Bacteria}

Bacteria used in these experiments were as follows: $E$. coli, ATCC 25922; hemolytic $S$. aureus, ATCC 25923; a clinical throat isolate of group A, $\beta$-hemolytic Streptococcus pyogenes; and a clinical blood isolate of Streptococcus pneumoniae type III (4). Cultures were maintained on sheep blood agar plates (BAPs) (BBL Microbiology Systems, Cockeysville, MD) and subcultured every 2 wk. E. coli and $S$. aureus were grown in trypticase soy broth (Difco Laboratories, Detroit, MI), and $S$. pyogenes and $S$. pneumoniae were grown in Todd-Hewitt broth (BBL Microbiology Systems).

\section{Preparation of ${ }^{3} \mathrm{H}$-labeled bacteria}

Bacteria were labeled by adding $0.1-7 \mathrm{ml}$ (depending on the species) of overnight culture to $200 \mathrm{ml}$ of medium containing $400 \mu \mathrm{Ci}$ of $\left[{ }^{3} \mathrm{H}\right]$ thymidine (ICN Biomedicals, Costa Mesa, CA; $60 \mathrm{Ci} / \mathrm{mmol}$ ), and by incubating the bacteria to mid-log phase in a shaking water bath at $37^{\circ} \mathrm{C}$. At the end of the incubation, $0.5 \mathrm{ml}$ of bacteria was removed, serially diluted, and plated on BAPs. The remaining bacteria were centrifuged at $4^{\circ} \mathrm{C}$, combined in sterile $0.15 \mathrm{M}$ saline, washed three times, and resuspended to $30 \mathrm{ml}$ in sterile saline. Bacteria then were heat-killed at $65^{\circ} \mathrm{C}$ for $1 \mathrm{~h}(S$. pneumoniae were heat-killed in $0.4 \%$ formalin), washed twice in saline, and stored in $30 \mathrm{ml}$ of saline containing $0.05 \%$ azide. A $50-\mu \mathrm{l}$ aliquot was solubilized in $1 \mathrm{ml}$ of BTS-450 (Beckman Instruments Inc., Fullerton, CA) for $1.5 \mathrm{~h}$ at $60^{\circ} \mathrm{C}$. Scintillation cocktail was added, and the suspension was counted in a liquid scintillation counter. The number of bacteria/cpm averaged between 600 and 1,000 .

\section{Serum}

Pooled human serum (PHS) was prepared from six donors by allowing blood to clot for $45 \mathrm{~min}$ at $25^{\circ} \mathrm{C}$ and $45 \mathrm{~min}$ at $4^{\circ} \mathrm{C}$. After centrifugation, serum was pooled, aliquoted, and stored frozen at $-80^{\circ} \mathrm{C}$ to preserve $\mathrm{C}$ activity. Aliquots of serum were thawed just before use, and used only once. In some experiments serum was treated with $5 \mathrm{mM}$ Mg-EGTA to chelate calcium so that only the alternate $C$ pathway was activated (37).

\section{Monocyte preparation and culture}

Citrate anticoagulated human blood was centrifuged at $300 \mathrm{~g}$ for 20 min at $25^{\circ} \mathrm{C}$, and platelet-rich plasma was removed. Mononuclear cells then were isolated from buffy coats by dextran sedimentation and Ficoll-Hypaque centrifugation (22). Monocytes were adhered to various substrates for $1 \mathrm{~h}$ at $37^{\circ} \mathrm{C}$ in $5 \% \mathrm{CO}_{2}-95 \%$ air in 24-well tissue culture plates (Costar Data Packaging Corp., Cambridge, MA). The adherent monocytes were washed, and then were studied immediately or cultured in M199 (Gibco Laboratories, Grand Island, NY) containing $10 \%$ autologous serum and $10 \mu \mathrm{g} / \mathrm{ml}$ gentamicin (Sigma Chemical Co., St. Louis, MO). Medium was replaced on day 3 when $\mathbf{M} \phi$ were cultured for $7 \mathrm{~d}(22)$.

\section{Preparation of coverslips coated with extracellular matrix proteins}

Collagen gels. Collagen gels were prepared as described by Kaplan and Gaudernack (27). Type I collagen from rat tails (Sigma Chemical Co.) was dissolved in $\times 1: 10 \mathrm{M} 199, \mathrm{pH} 3.0$ at a concentration of $1 \mathrm{mg} / \mathrm{ml}$, and aliquots of $0.25 \mathrm{ml}$ were dispensed into the wells of 24-well tissue culture plates. To form gels, $25 \mu \mathrm{l}$ of $\times 10 \mathrm{M} 199$ and $12.5 \mu \mathrm{l}$ of $0.142 \mathrm{~N}$ $\mathrm{NaOH}$ were added simultaneously to each well, the contents were mixed, and the plates were incubated for $2 \mathrm{~h}$ at $37^{\circ} \mathrm{C}$. Collagen gels and collagen-coated coverslips were washed four times with HBSS containing $20 \mathrm{mM}$ Hepes (Hanks'-Hepes), and monocytes were adhered for $1 \mathrm{~h}$ at $37^{\circ} \mathrm{C}$.

On SDS-PAGE, collagen from Sigma Chemical Co. showed characteristic $\alpha 1(\mathrm{I})$ and $\alpha 2$ (I) chains as well as some $\beta$ chains, which were identical to those observed with purified type I collagen (kindly pro- vided by Dr. Winston Kao, Department of Ophthalmology, University of Cincinnati College of Medicine). No bands were observed that comigrated with purified fibronectin (Collaborative Research, Bedford, MA), and no other contaminating proteins were observed (data not shown).

Vitronectin. Purified vitronectin was a gift of Dr. Charles Parker, VA Medical Center, Salt Lake City, UT, and was used as described (33). Coverslips were covered with $0.3 \mathrm{ml}$ of vitronectin $(50 \mu \mathrm{g} / \mathrm{ml})$ and incubated for $2 \mathrm{~h}$ at $25^{\circ} \mathrm{C}$. Coverslips were washed twice in Hanks'Hepes, and monocytes were adhered for $1 \mathrm{~h}$ at $37^{\circ} \mathrm{C}$.

Gelatin-coated fibronectin. Fibronectin-coated coverslips were prepared by the method of Bevilaqua et al. (38). Coverslips were incubated with gelatin $(2 \mathrm{mg} / \mathrm{ml})$ for $1 \mathrm{~h}$ at $37^{\circ} \mathrm{C}$, excess gelatin was aspirated, and plates were incubated overnight at $50^{\circ} \mathrm{C}$. Plates were irradiated under UV light for $1 \mathrm{~h}, 0.3 \mathrm{ml}$ of platelet-free plasma was added, and the plates were incubated for $30 \mathrm{~min}$ at $25^{\circ} \mathrm{C}$, and then for $60 \mathrm{~min}$ at $4^{\circ} \mathrm{C}$. Excess plasma was removed by aspiration, the wells were washed twice in Hanks'-Hepes, and monocytes were adhered for $1 \mathrm{~h}$ at $37^{\circ} \mathrm{C}$.

\section{Phagocytosis of ${ }^{3} \mathrm{H}$-labeled bacteria}

Heat-killed, radiolabeled bacteria were suspended to $6 \times 10^{8} / \mathrm{ml}$ in Hanks'-Hepes containing $10 \%$ PHS and incubated for $20 \mathrm{~min}$ at $37^{\circ} \mathrm{C}$. Opsonized bacteria were studied as they were, or were washed twice in Hanks'-Hepes containing $0.25 \%$ BSA (HBSA) and then resuspended to $6 \times 10^{8} / \mathrm{ml} .0 .1 \mathrm{ml}$ of opsonized bacteria was added to adherent monocyte $/ \mathrm{M} \phi$ and incubated for varying periods of time at $25^{\circ} \mathrm{C}$. At the end of the incubation period, monolayers were washed six times with HBSA to remove nonadherent bacteria. Monolayers were lysed with $0.1 \mathrm{ml}$ of $0.05 \%$ Triton $\mathrm{X}-100$ for $15 \mathrm{~min}$ at $37^{\circ} \mathrm{C}$. Lysed cells and bacteria were transferred to a $17 \times 100$-mm polypropylene tube, the wells were washed twice with $0.2 \mathrm{ml}$ of sterile water, and the wash supernates were combined with the lysate. The bacteria were solubilized, scintillation cocktail was added, and the mixture was poured into scintillation vials for counting. Control wells contained bacteria only, and the counts per minute obtained were subtracted as background to account for nonspecific adherence of the bacteria to the plastic $(<100$ cpm) or the collagen gels $(<500 \mathrm{cpm})$. Removal of the bacteria also was confirmed by visual inspection on an inverted microscope. Monocytes that underwent all manipulations except incubation with bacteria were treated with ZAP-OGLOBIN II (Coulter Diagnostics, Hialeah, FL) to lyse the external membrane of the cells. Nuclei then were quantified on a Sysmex Microcell CC-110 counter (American Scientific Products, Columbus, $\mathrm{OH}$ ). Results are expressed as the mean \pm SEM of the number of bacteria ingested per phagocyte.

\section{Monocyte $/ M \phi$ bactericidal assay}

The bactericidal assay described by Leijh et al. (39) for quantifying killing in the absence of continuing phagocytosis was modified for study of adherent phagocytes. Except where noted, buffers did not contain antibiotic. Mid-log-phase bacteria were centrifuged, washed once in Hanks'-Hepes, and resuspended to $5 \mathrm{ml}$ in HBSA. Bacteria were diluted 1:100, and $0.6-\mathrm{ml}$ aliquots were further diluted to $1.2 \mathrm{ml}$ in HBSA containing 10\% PHS. Bacteria were opsonized for $20 \mathrm{~min}$ at $37^{\circ} \mathrm{C}$, washed twice with HBSA, and then resuspended to $1.2 \mathrm{ml}$. Opsonized bacteria $(0.1 \mathrm{ml})$ were added to each well and incubated for $10 \mathrm{~min}$ at $25^{\circ} \mathrm{C}$ to allow for phagocytosis. The inoculum was aspirated, and the monolayers were washed three times with HBSA, and once with HBSA containing $10 \mu \mathrm{g} / \mathrm{ml}$ of gentamicin. The gentamicin wash was added to kill the few extracellular bacteria that were observed to adhere to the collagen gels. Viable bacteria, unlike heat-killed bacteria, were more prone to stick to the collagen gels, particularly $S$. aureus. (Incubation of collagen-adherent monocytes with gentamicin reduced the number of viable bacteria recovered compared to untreated collagen-adherent monocytes. No viable bacteria were recovered from collagen gels incubated with bacteria alone and then washed with gentamicin; bacteria were recovered from collagen gels incubated with bacteria alone and then washed without gentamicin. Evidence that 
gentamicin did not effect the number of intracellular bacteria came from control experiments with plastic-adherent monocytes. Thus, identical numbers of viable intracellular bacteria were recovered from plastic-adherent monocytes incubated with or without gentamicin.) Monolayers were covered with $0.2 \mathrm{ml}$ of HBSA or $0.2 \mathrm{ml}$ of HBSA containing 50\% PHS, and incubated for $0,30,60$, or $120 \mathrm{~min}$ at $37^{\circ} \mathrm{C}$ in $5 \% \mathrm{CO}_{2}-95 \%$ air. At the end of each time period, the cells were washed twice with cold HBSA, and monolayers lysed in $1 \mathrm{ml}$ of sterile water. After vigorous agitation, the lysate was transferred to a tube containing $9 \mathrm{ml}$ of water, and the bacteria were serially diluted and plated on BAPs. Plates were incubated overnight at $37^{\circ} \mathrm{C}$, and viable colonies enumerated. Results are expressed as the number of viable bacteria remaining at each time point. In preliminary experiments we found that significant killing occurred during the $10 \mathrm{~min}$ of phagocytosis, particularly of $S$. aureus by monocytes. To obtain a more accurate quantitation of the number of microorganisms initially phagocytosed, opsonized bacteria were incubated with adherent monocytes in the presence of $3.2 \mathrm{mM}$ phenylbutazone to prevent the killing of ingested bacteria $(39,40)$. The viable bacteria count obtained from these wells was used as a measure of the number of microorganisms initially ingested.

Preparation of C3- and IgG-coated sheep erythrocytes (E)

Sheep E bearing $\mathrm{C} 3 \mathrm{~b}$ and $\mathrm{iC} 3 \mathrm{~b}$ (EC3b and EC $3 \mathrm{bi}$ ) were prepared with purified components of the alternate $\mathrm{C}$ pathway as previously described (24). EC3b(i) used in these experiments had 4-5 $\times 10^{4} \mathrm{C} 3$ molecules bound per E (24). To prepare IgG-coated E (EIgG), E (1 $\times 10^{9} / \mathrm{ml}$ ) were mixed with an equal volume of a 1:250 dilution of rabbit IgG anti-E (Cordis Laboratories, Miami, FL), and incubated for $30 \mathrm{~min}$ at $37^{\circ} \mathrm{C}$ and $30 \mathrm{~min}$ at $4^{\circ} \mathrm{C}(22)$. EIgG prepared in this manner were bound and ingested by $50-60 \%$ of freshly isolated monocytes (22).

\section{Phagocytosis of ligand-coated $E$}

Binding and ingestion of EC $3 \mathrm{~b}(\mathrm{i})$ and EIgG by adherent monocyte/M $\phi$ were quantified as described previously $(22,24)$. After incubation of ligand-coated $\mathrm{E}\left(2 \times 10^{7}\right)$ with monocyte/M $\phi$ for $1 \mathrm{~h}$ at $37^{\circ} \mathrm{C}$ in $5 \%$ $\mathrm{CO}_{2}-95 \%$ air, unbound $\mathrm{E}$ were removed by washing with $\mathrm{HBSA}$, and bound but uningested $\mathrm{E}$ were lysed with an $\mathrm{NH}_{4} \mathrm{Cl}$ lysing buffer. The monolayers then were fixed in $2 \%$ glutaraldehyde- $1 \%$ sucrose in 0.01 $\mathrm{M}$ phosphate buffer, $\mathrm{pH}$ 7.4. Coverslips were sealed cell-side-down on microscope slides, and binding and ingestion were quantified by counting 100-200 cells per coverslip via phase-contrast microscopy at $\times 1,000$. Results are expressed as percent rosettes (the percentage of cells that bound three or more $E$ ), percent ingestion (the percentage of cells that ingested one or more E), and the phagocytic index (PI, the total number of $E$ ingested per 100 cells).

In some experiments, phagocytosis was quantified using ${ }^{51} \mathrm{Cr}$-labeled $\mathrm{E}$ as described previously (22). Phagocytosis experiments were performed as described for unlabeled E, except that after lysis of unbound $\mathrm{E}$, monocytes were lysed with $1 \mathrm{ml}$ of $0.05 \%$ Triton X-100 (Fisher Scientific Co., Pittsburgh, PA). The wells were washed once with HBSA, the lysate and wash supernate were pooled, and radioactivity was quantified in a Packard AUTO-GAMMA 500C (Packard Instruments Co., Inc., Downers Grove, IL). Adherent monocytes were quantified as described above, and results were expressed as the mean $\pm \mathrm{SEM}$ of the number of $\mathrm{E}$ ingested per monocyte. All experiments were performed in triplicate.

\section{Superoxide anion production}

Superoxide anion $\left(\mathrm{O}_{2}^{-}\right)$generation by adherent monocytes was quantified as the superoxide dismutase (SOD)-inhibitable reduction of ferricytochrome $c$ (type III, Sigma Chemical Co.) (41). Zymosan was opsonized in $10 \%$ PHS at $2 \times 10^{8}$ particles $/ \mathrm{ml}$ for $20 \mathrm{~min}$ at $37^{\circ} \mathrm{C}$. After washing twice in HBSA, opsonized zymosan was resuspended in Krebs-Ringer phosphate buffer with $0.2 \%$ dextrose containing $80 \mu \mathrm{M}$ cytochrome $c$. Adherent monocytes were washed, and then incubated for $1 \mathrm{~h}$ at $37^{\circ} \mathrm{C}$ with opsonized zymosan $\left(2 \times 10^{7}\right.$ particles $\left./ \mathrm{ml}\right)$ or 100 $\mathrm{ng} / \mathrm{ml}$ of phorbol myristate acetate (PMA) (Sigma Chemical Co.) in the Krebs-Ringer phosphate dextrose buffer containing cytochrome $c$. Control wells contained cytochrome $c$ without a stimulus (resting cells), or the stimulus plus $40 \mu \mathrm{g} / \mathrm{ml}$ of SOD (Sigma Chemical Co.). At the end of the incubation, the absorbance of the supernates at $550 \mathrm{~nm}$ was compared to a blank that underwent all manipulations but contained only cytochrome $c$. Results are expressed as nanomoles of cytochrome $c$ reduced per $1 \times 10^{5}$ monocytes per hour.

\section{Results}

Phagocytosis of opsonized bacteria by collagen- vs. plastic-adherent monocytes. Phagocytosis of ${ }^{3} \mathrm{H}$-labeled serum-opsonized $E$. coli by monocytes adhered to collagen gels or to the plastic surface of 24-well tissue culture plates was quantified after varying periods of time. Both the rate of phagocytosis and the number of $E$. coli ingested by collagen-adherent monocytes was greater than that of plastic-adherent monocytes (Fig. 1). After $30 \mathrm{~min}$ of incubation, collagen-adherent monocytes ingested 3.5-fold more $E$. coli than plastic-adherent cells. The enhanced rate and phagocytic capacity of collagen-adherent vs. plastic-adherent monocytes were maintained during 24 and $48 \mathrm{~h}$. of culture. After 24 and $48 \mathrm{~h}$, collagen-adherent $\mathrm{M} \phi$ ingested 4.7- and 3.5- fold more $E$. coli per $\mathrm{M} \phi$, respectively, than $\mathbf{M} \phi$ cultured on plastic (data not shown).

To determine whether the enhanced phagocytosis by collagen-adherent monocytes was applicable to other bacteria, we quantified the phagocytosis of other species of bacteria by collagen- vs. plastic-adherent monocytes. Collagen-adherent monocytes ingested 2.5-12-fold more opsonized $E$. coli, $S$. aureus, $S$. pyogenes, and $S$. pneumoniae than plastic-adherent monocytes (Fig. 2).

Fig. 3 shows that opsonization in fresh PHS was required for phagocytosis of $E$. coli and $S$. pneumoniae by collagen-ad-

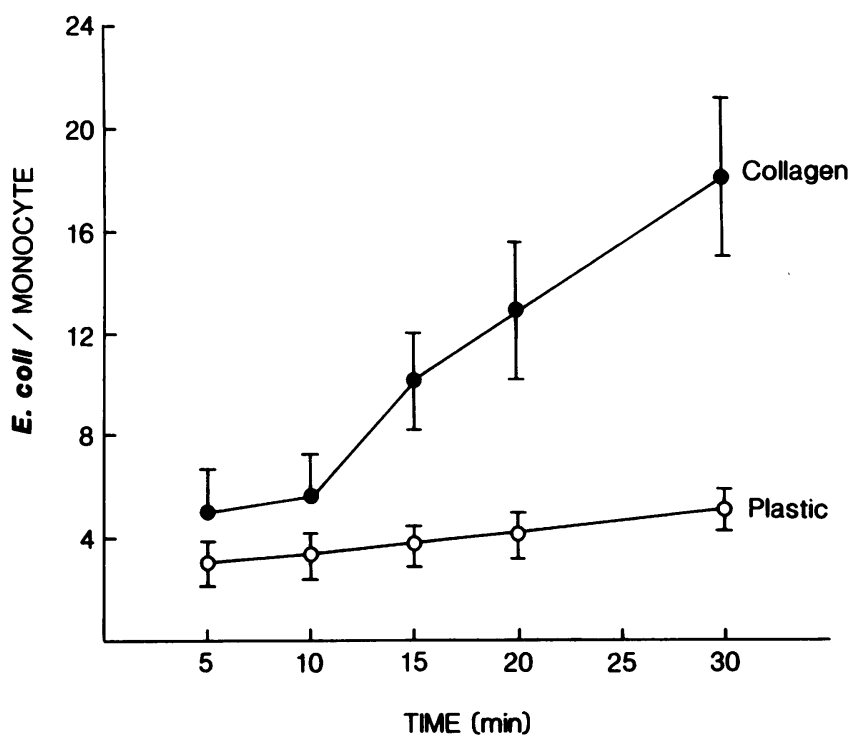

Figure 1. Kinetics of collagen- vs. plastic-adherent monocyte phagocytosis of ${ }^{3} \mathrm{H}$-labeled $E$. coli. $\left[{ }^{3} \mathrm{H}\right]$ Thymidine-labeled E. coli $\left(6 \times 10^{8}\right)$ $\mathrm{ml}$ ) were opsonized in $10 \%$ PHS for $20 \mathrm{~min}$ at $37^{\circ} \mathrm{C}$. After opsonization, bacteria were washed twice in HBSA, and resuspended to 6 $\times 10^{8} / \mathrm{ml}$ in HBSA. Aliquots of $6 \times 10^{7}$ bacteria then were incubated with collagen- or plastic-adherent monocytes and phagocytosis was quantified after $5-30 \mathrm{~min}$ at $25^{\circ} \mathrm{C}$. Results are presented as the mean $\pm \operatorname{SEM}(n=5)$ of the number of $E$. coli ingested per monocyte. 


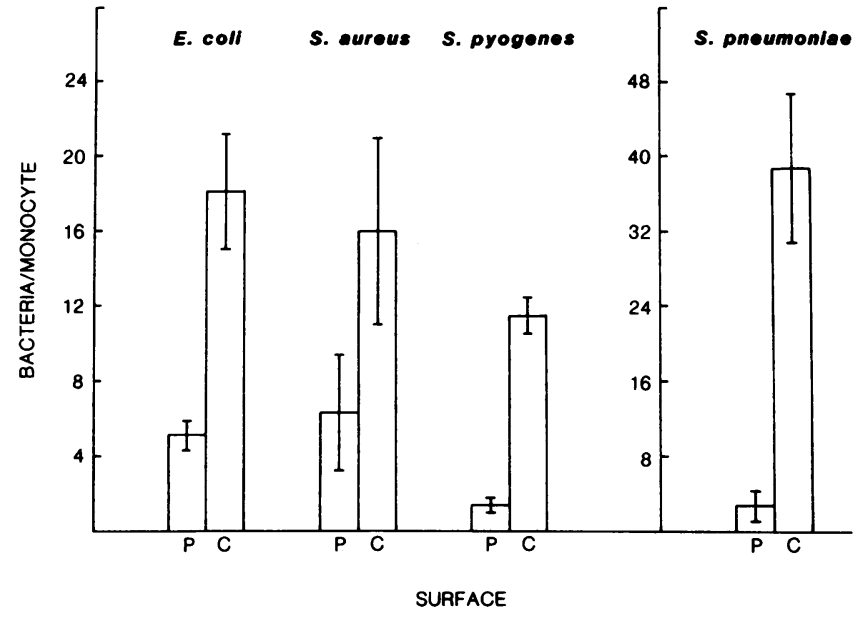

Figure 2. Phagocytosis of ${ }^{3} \mathrm{H}$-labeled bacteria by collagen- vs. plasticadherent monocytes. Collagen- and plastic-adherent monocytes were incubated with $6 \times 10^{7}$ opsonized $\left[{ }^{3} \mathrm{H}\right]$ thymidine labeled $E$. coli, $S$. aureus, $S$. pyogenes, or $S$. pneumoniae and phagocytosis was quantified after $30 \mathrm{~min}$ at $25^{\circ} \mathrm{C}$. Results are presented as the mean \pm SEM $(n=3-4)$ of the number of bacteria ingested per monocyte. P, plastic; $\mathrm{C}$, collagen.

herent monocytes. Similar results were obtained with $S$. aureus and $S$. pyogenes (data not shown). Phagocytosis of bacteria opsonized in serum chelated with $5 \mathrm{mM} \mathrm{Mg-EGTA} \mathrm{(37)}$ was equivalent to that obtained with untreated serum, demonstrating that opsonization of these bacteria via the alternate $C$ pathway was sufficient for optimum phagocytosis. Opsonization of bacteria in heat-inactivated serum resulted in intermediate levels of ingestion, presumably due to antibody present in the PHS (Fig. 3).
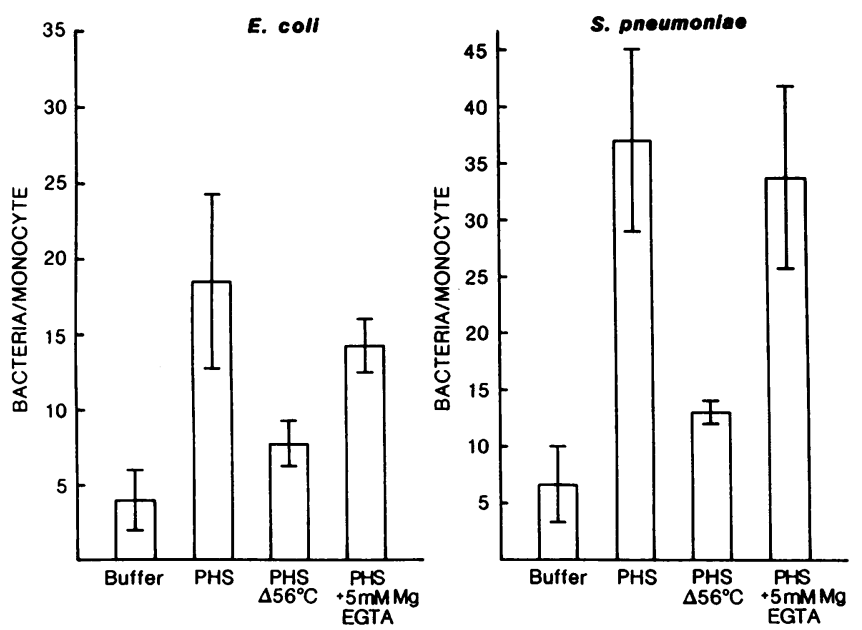

Figure 3. Requirement for opsonization of ${ }^{3} \mathrm{H}$-labeled $E$. coli and $S$. pneumoniae for phagocytosis by collagen-adherent monocytes. $\left[{ }^{3} \mathrm{H}\right]-$ Thymidine-labeled bacteria were opsonized for $20 \mathrm{~min}$ at $37^{\circ} \mathrm{C}$ in $10 \%$ PHS, $10 \%$ PHS heated at $56^{\circ} \mathrm{C}$ for $60 \mathrm{~min}, 10 \%$ PHS containing $5 \mathrm{mM}$ Mg-EGTA, or buffer. Aliquots of $6 \times 10^{7}$ bacteria were incubated with collagen-adherent monocytes and phagocytosis was quantified after $30 \mathrm{~min}$ at $25^{\circ} \mathrm{C}$. Results are presented as the mean \pm SEM $(n=3)$ of the number of bacteria per monocyte.
Phagocytoses of opsonized bacteria by plastic-adherent monocytes vs. cultured monocyte-derived M $\phi$. Phagocytosis of opsonized $E$. coli and $S$. aureus by plastic-adherent monocytes and adherently cultured $M \phi$ was quantified after varying periods of time. Fig. 4 shows that the rate of phagocytosis and the number of bacteria ingested by $\mathbf{M} \phi$ was greater than that of freshly isolated monocytes. After $30 \mathrm{~min}, \mathbf{M} \phi$ had ingested 3.7-fold more $E$. coli and 2.4-fold more $S$. aureus than monocytes.

Fig. 5 shows that opsonization with fresh PHS was required for phagocytosis of $E$. coli and $S$. aureus by plastic-adherent monocytes and cultured $\mathbf{M} \phi$. Opsonization in heat-inactivated PHS markedly reduced the phagocytosis of $E$. coli by monocytes and $\mathbf{M} \phi$. In contrast, monocyte/M $\phi$ phagocytosis of $S$. aureus opsonized in heat-inactivated serum was $56 \%$ and $63 \%$, respectively, of that obtained with unheated serum, indicating that the PHS contained a considerable amount of antibody to this strain of $S$. aureus. Opsonization via the alternate $C$ pathway was sufficient for optimum phagocytosis by both plasticadherent monocytes and cultured $\mathbf{M} \phi$.

These data show that collagen-adherent monocytes ingested as many or more opsonized bacteria as cultured $\mathbf{M} \phi$ (Figs. 1, 2, and 4). Thus, collagen-adherent monocytes ingested a mean \pm SEM of $18.6 \pm 5.8(n=3) E$. coli per cell, and $16.0 \pm 10.5(n=3) S$. aureus per cell. By comparison, cultured macrophages ingested $8.9 \pm 1.9(n=4)$ and $15.9 \pm 1.8(n=3)$ opsonized $E$. coli and $S$. aureus per $\mathrm{M} \phi$, respectively. Therefore, adherence of freshly isolated monocytes to collagen gels abrogated the requirement for long-term in vitro culture to achieve the same phagocytic capacity observed for 7-d cultured $\mathbf{M} \phi$. However, adherence of monocytes to collagen gels did not abrogate the requirement for serum opsonization.

Bactericidal activity of collagen- vs. plastic-adherent monocytes. We next sought to quantify and compare the bactericidal activity of collagen-vs. plastic-adherent monocytes. To quantify bactericidal activity, monocytes were incubated for $10 \mathrm{~min}$ with opsonized $E$. coli or $S$. aureus, and uningested organisms were removed by washing. Fresh buffer or buffer containing $50 \%$ PHS was added to the monolayers, and killing was quantified after incubation for 30,60 , and $120 \mathrm{~min}$ at $37^{\circ} \mathrm{C}$. Identical numbers of monocytes adhered to both substrates, and, therefore, the results are presented as the amount of killing observed in each monolayer. For eight individual donors, the mean \pm SEM of the number of monocytes that adhered to collagen gels or plastic was $3.5 \pm 0.2 \times 10^{5}$ and $3.6 \pm 0.1 \times 10^{5}$, respectively. After 24 and $48 \mathrm{~h}$ of culture, the number of collagen-adherent $\mathrm{M} \phi$ was $3.3 \pm 0.1 \times 10^{5}$ and $3.1 \pm 0.2 \times 10^{5}$ cells, respectively. The number of $\mathrm{M} \phi$ adherent to plastic at 24 and $48 \mathrm{~h}$ was $3.3 \pm 0.2 \times 10^{5}$ and $3.0 \pm 0.2 \times 10^{5}$ cells, respectively. Thus, few M $\phi$ were lost after 24 and $48 \mathrm{~h}$ of culture on either substrate.

After $10 \mathrm{~min}$ of phagocytosis collagen-adherent monocytes ingested almost twice as many $E$. coli and fourfold more $S$. aureus than plastic-adherent cells. Despite the extra bacterial load, collagen-adherent monocytes killed $94 \%$ of ingested $E$. coli and $97 \%$ of ingested $S$. aureus when serum was present during the bactericidal assay. In the absence of extracellular serum, $80 \%$ of $E$. coli and $94 \%$ of $S$. aureus were killed (Fig. 6). Plastic-adherent monocytes killed $92 \%$ of ingested $E$. coli and $65 \%$ of ingested $S$. aureus in the presence of extracellular serum (Fig. 6). 


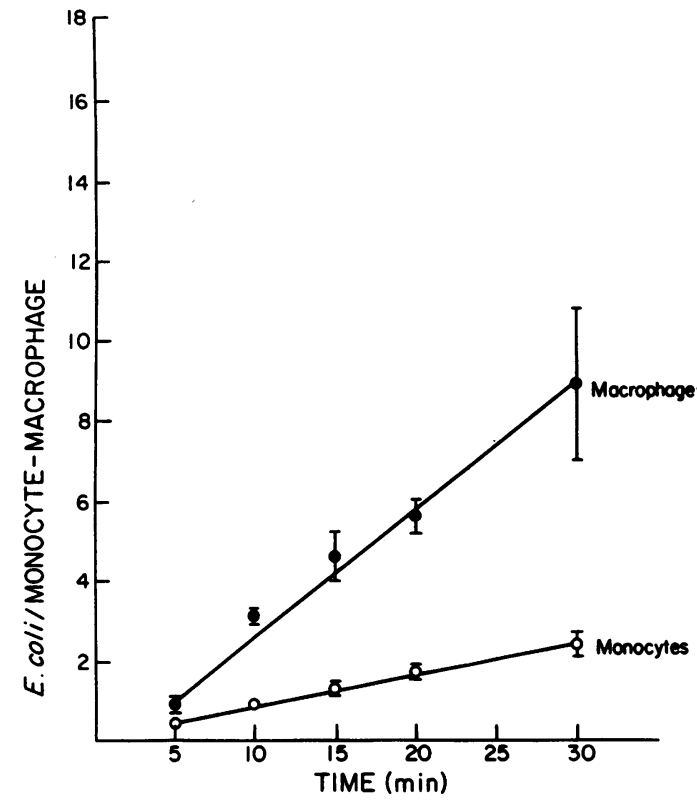

The bactericidal activity of monocytes for $E$. coli and $S$. aureus was maintained over 24-48 h of culture on both collagen gels and plastic. After $10 \mathrm{~min}$ of phagocytosis, collagenadherent $M \phi$ ingested 2.4- and 3-fold more E. coli at 24 and 48 h, respectively; and 2- and 6-fold more $S$. aureus at 24 and 48 h, respectively. As was observed for freshly adherent monocytes, cultured collagen-adherent $\mathrm{M} \phi$ killed $>90 \%$ of ingested $E$. coli and $S$. aureus after $2 \mathrm{~h}$. Again, optimum killing of $E$. coli, but not killing of $S$. aureus, required the presence of extracellular serum. Cultured plastic-adherent $\mathbf{M} \phi$ killed $83 \%$ and $91 \%$ of ingested $E$. coli at 24 and $48 \mathrm{~h}$, respectively; and killed $68 \%$ and $83 \%$ of ingested $S$. aureus at 24 and $48 \mathrm{~h}$, respectively.

Bactericidal activity of monocytes vs. cultured $M \phi$. Next we quantified and compared the bactericidal activity of plasticadherent monocytes vs. 7-d cultured $\mathrm{M} \phi$ against $E$. coli and $S$. aureus. Monocytes killed $98 \%$ and $91 \%$ of ingested $E$. coli and $S$. aureus, respectively, after 2 h (Fig. 7, upper panels). In contrast, 7-d cultured $\mathbf{M} \phi$ only were bacteriostatic. As was found for collagen-adherent monocytes, the presence of extra-

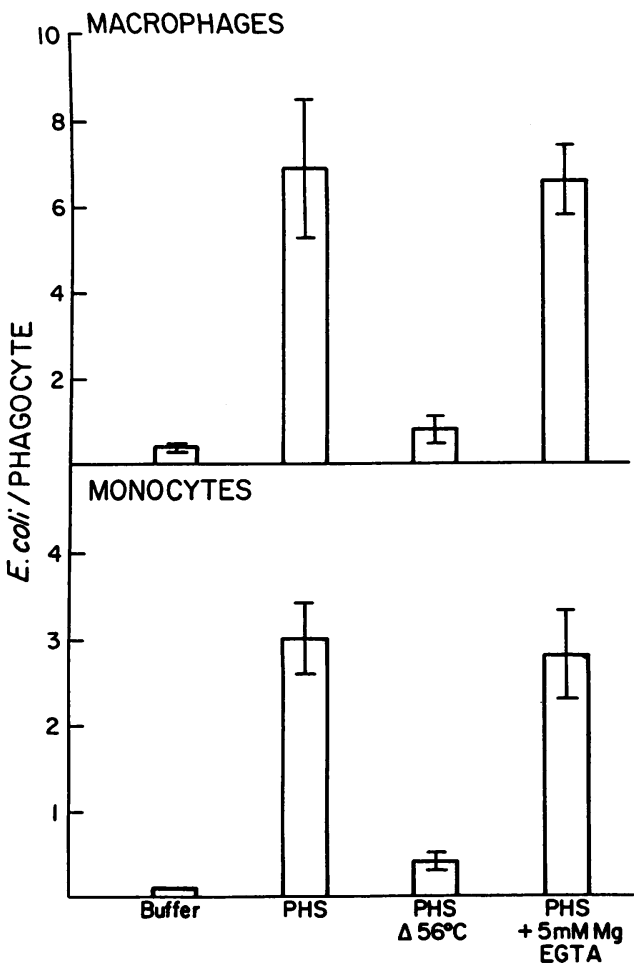

Figure 5. Requirement for opsonization of ${ }^{3} \mathrm{H}$-labeled $E$. coli and $S$. aureus for phagocytosis by plastic-adherent monocytes and cultured $M \phi .\left[{ }^{3} \mathrm{H}\right]$ Thymidine-labeled bacteria were opsonized for $20 \mathrm{~min}$ at $37^{\circ} \mathrm{C}$ in $10 \%$ PHS, $10 \%$ PHS heated at $56^{\circ} \mathrm{C}$ for $60 \mathrm{~min}, 10 \%$ PHS containing $5 \mathrm{mM} \mathrm{Mg-EGTA}$, or buffer. After opsonization, bacteria were washed twice in HBSA, and resuspended to 6 $\times 10^{8} / \mathrm{ml}$ in HBSA. Aliquots of $6 \times 10^{7}$ bacteria were incubated with monocyte/M $\phi$ and phagocytosis was quantified after 30 min at $25^{\circ} \mathrm{C}$. Results are presented as the mean \pm SEM ( $n$ $=4-5$ ) of the number of bacteria ingested per phagocyte. 

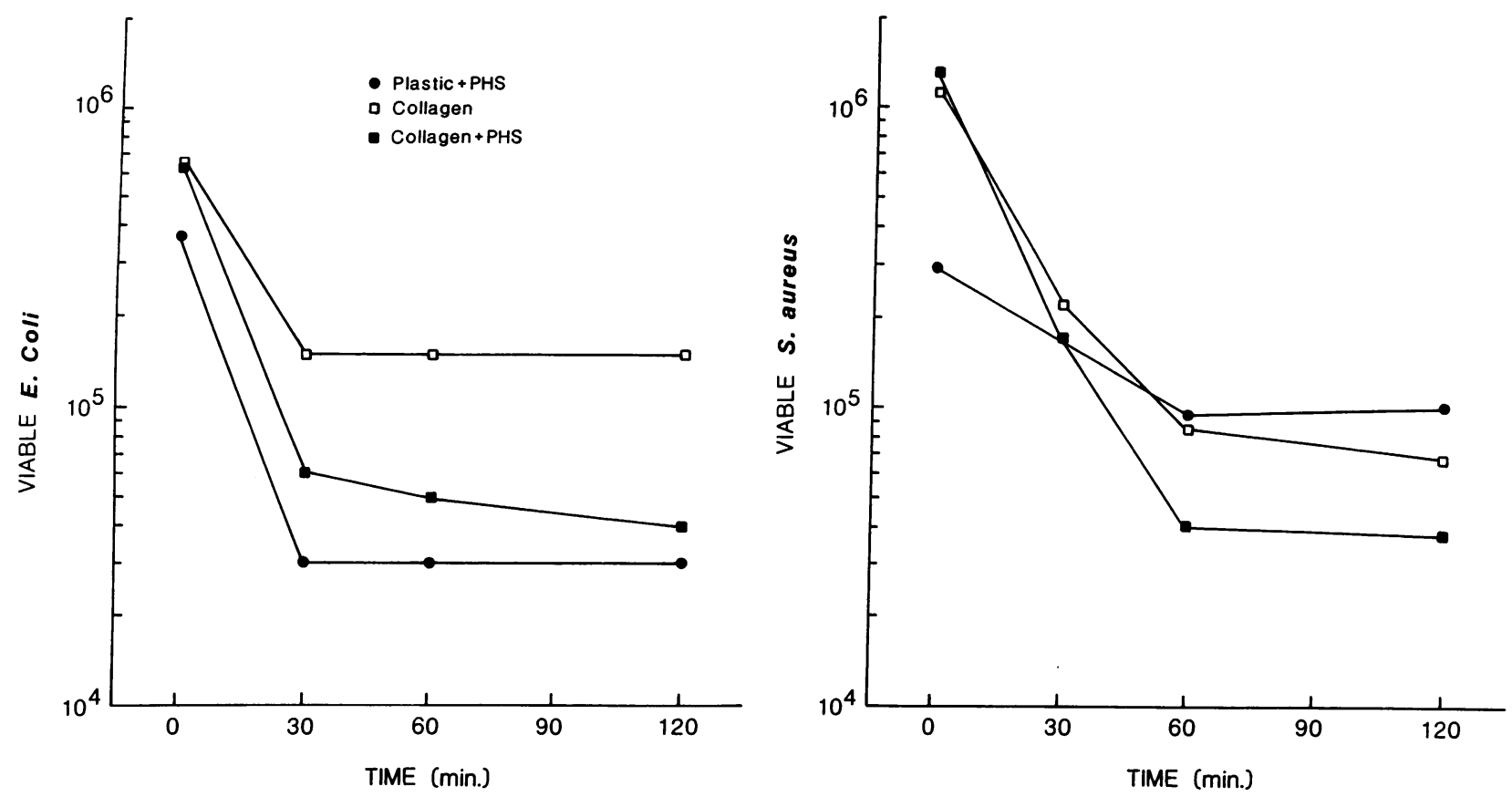

Figure 6. Collagen- and plastic-adherent monocyte bactericidal activity against $E$. coli and $S$. aureus. Mid-log-phase bacteria were opsonized in $10 \%$ PHS and washed twice in HBSA, and $0.1-\mathrm{ml}$ aliquots were incubated with monocytes for $10 \mathrm{~min}$ at $37^{\circ} \mathrm{C}$ to allow for phagocytosis. After washing off the noningested bacteria, plastic-adherent monocytes were covered with HBSA (•), and collagen-adherent monocytes were covered with HBSA ( $\square$ ) or HBSA containing 50\% PHS ( $)$. Bactericidal activity was quantified after 30,60 , and 120 min at $37^{\circ} \mathrm{C}$. The results show the number of remaining viable bacteria at each time point and are the means from four separate experiments.

cellular serum was required for optimum killing of $E$. coli by plastic-adherent monocytes, but was not required for killing $S$. aureus.

Activation of $C R_{1}$ and $C R_{3}$ for phagocytosis by adherence of monocytes to collagen gels. The increased phagocytosis of opsonized bacteria demonstrated by collagen-adherent monocytes might be explained by an overall increase in the phagocytic activity of monocytes, or by activation of individual membrane receptors for enhanced phagocytosis. Since opsonization of these bacteria with $\mathrm{C} 3 \mathrm{~b}(\mathrm{i}) / \mathrm{IgG}$ is required for recognition and ingestion, we sought to determine if adherence of monocytes to collagen gels might have a specific regulatory effect on CR and FcR function. Monocytes were adhered to collagen gels or glass coverslips, and attachment and ingestion of EC $3 \mathrm{~b}$ and EC3bi quantified immediately after adherence, or after culture of monocytes for 24 and $48 \mathrm{~h}$. The results of these experiments are shown in Fig. 8. Zero (0) time in culture refers to monocytes studied immediately after the $1 \mathrm{~h}$ of adherence.

As has been shown by us $(22,24)$ and others $(21,23)$, glass-adherent monocytes avidly bind EC3b and EC3bi (Fig. 8 $A$ ), but do not ingest them (Fig. 8, $B$ and $C$ ). In contrast, collagen-adherent monocytes not only bound EC3b and EC3bi (Fig. $8 D$ ), but ingested them as well (Fig. 8, $E$ and $F$ ). After adherence to collagen gels, $34 \pm 4 \%$ of monocytes ingested an average of $2.5 \mathrm{EC} 3 \mathrm{~b}$ per monocyte, and $44 \pm 5 \%$ of cells ingested 2.9 EC3bi per monocyte. As reported previously (22), culture of monocytes for $24-48 \mathrm{~h}$ on coverslips resulted in a decrease in the capacity of these cells to bind EC $3 \mathrm{~b}$ and EC3bi (Fig. $8 \mathrm{~A}$ ). In contrast, monocytes cultured for $24-48 \mathrm{~h}$ on collagen gels maintained their ability to form rosettes with
EC3b(i) (Fig. $8 \mathrm{D}$ ), and the number of particles ingested increased with time in culture (Fig. $8 F$ ). These data confirm the report of Kaplan and Gaudernack (27) that monocyte CR were activated for phagocytosis by $48 \mathrm{~h}$ of culture on collagen gels.

Enhancement of FcR-mediated phagocytosis by adherence of monocytes to collagen gels. In conjunction with the experiments on CR-mediated phagocytosis, FcR-mediated phagocytosis also was quantified. Freshly isolated collagen-adherent monocytes ingested more than twice as many EIgG as did glass-adherent monocytes ( $\mathrm{PI}=315 \pm 101$ vs. $135 \pm 11$, respectively) (Fig. 8, $C$ and $F$ ), although the percentage of phagocytic monocytes on both surfaces was the same (Fig. 8, $B$ and $E$ ). The PI of collagen-adherent monocytes remained unchanged through 24 and $48 \mathrm{~h}$ of culture, and was always greater than the PI of plastic-adherent monocytes (Fig. 8, $C$ and $F$ ).

To determine whether the number of EIgG ingested by plastic- vs. collagen-adherent monocytes, was dependent on the concentration of antibody used to prepare the EIgG, sheep E were labeled with ${ }^{51} \mathrm{Cr}$ and sensitized with varying concentrations of IgG anti-E, and phagocytosis of ${ }^{51} \mathrm{Cr}$-labeled EIgG was quantified. This assay procedure was used for these experiments because monocytes adherent to collagen gels did not spread well and remained rounded up, and ingestion was difficult to quantify accurately if more than five $\mathrm{E}$ were present in a single monocyte.

At all four concentrations of antibody tested, collagen-adherent monocytes ingested approximately twice as many EIgG/cell as plastic-adherent monocytes (Fig. 9). Thus, in- 

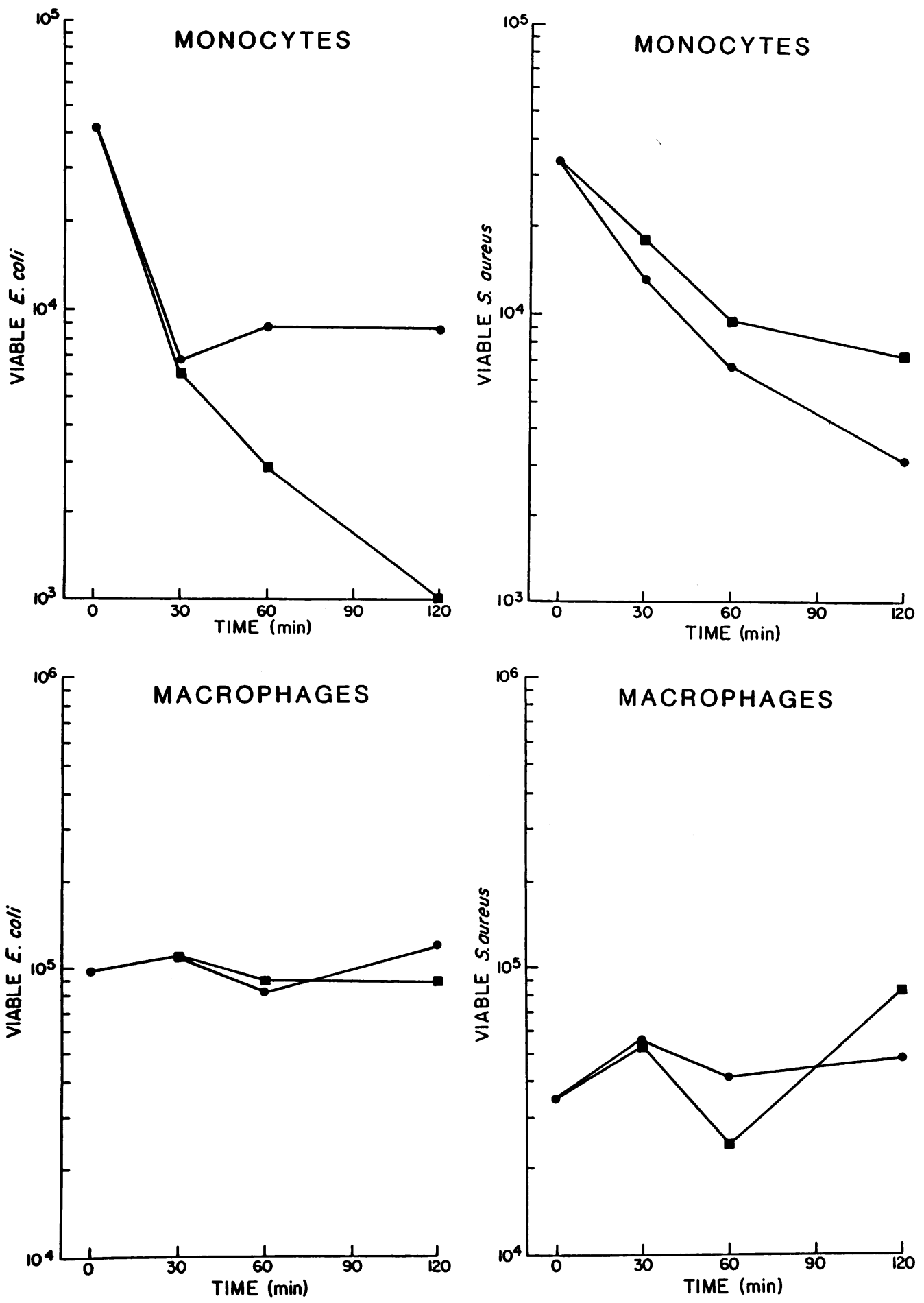

Figure 7. Monocyte/M $\phi$ bactericidal activity against $E$. coli and S. aureus. Phagocytic bactericidal activity was quantified as described in Fig. 6. Monolayers were covered with HBSA $(\bullet)$ or HBSA containing 50\% PHS $(\boldsymbol{\square})$ and bactericidal activity was quantified after 30,60 , and $120 \mathrm{~min}$ at $37^{\circ} \mathrm{C}$. The results show the number of remaining viable bacteria at each time point, and are the means from two experiments.

creased FcR-mediated phagocytosis by collagen-adherent monocytes was observed independent of the amount of antibody used to prepare the EIgG.

Effect of collagen vs. collagen gels on monocyte CR- and FcR-mediated phagocytosis. To determine whether augmentation of monocyte receptor function required that the collagen be in the form of a hydrated collagen lattice (which is the form of collagen in extracellular connective tissue matrices
[42]), monocytes were adhered to glass coverslips, or coverslips coated with collagen, collagen gels, fibronectin, or vitronectin, and attachment and ingestion of EC3b, EC3bi, and EIgG were quantified. Monocytes adherent to glass, vitronectin, or fibronectin, did not ingest EC3b or EC3bi, confirming our previous results (22) and the reports of others $(21,30,33)$. Monocytes adherent to collagen demonstrated some ingestion of EC3b(i), but optimum phagocytosis of these particles required adher- 

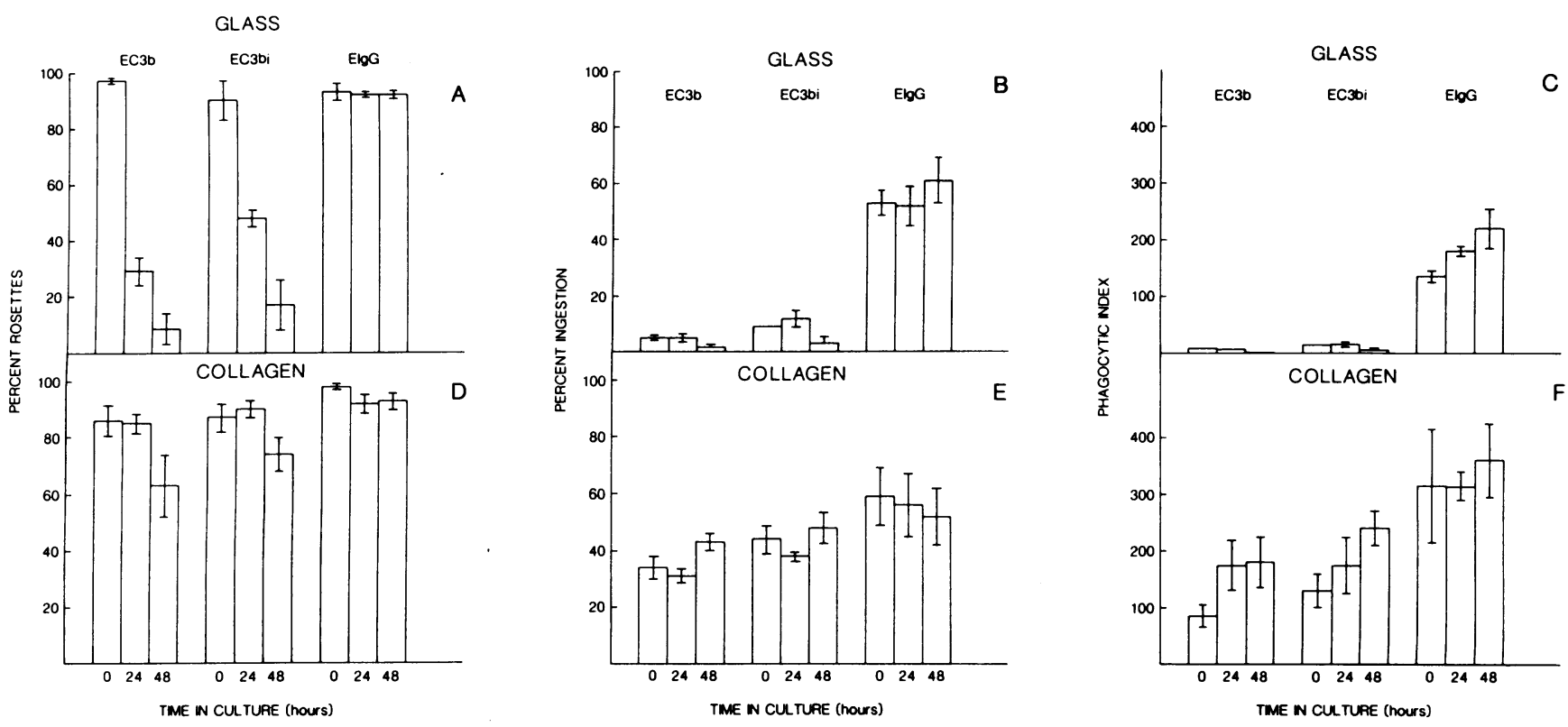

Figure 8. Binding and ingestion of EC3b(i) and EIgG by collagen- and plastic-adherent monocytes cultured for 0,24 , and $48 \mathrm{~h}$. Ligand-coated $\mathrm{E}\left(2 \times 10^{7}\right)$ were added to freshly isolated monocytes ( 0 time in culture) or monocytes cultured for 24 and $48 \mathrm{~h}$ on glass coverslips or collagen gels. Attachment and ingestion was quantified after $1 \mathrm{~h}$ at $37^{\circ} \mathrm{C}$. Results are presented as the mean $\pm \mathrm{SEM}$ of four to seven experiments. The upper panels show the results obtained with glass-adherent monocytes, and the lower panels show the results obtained with collagen-adherent monocytes. $(A$ and $D)$ Percent rosettes; $(B$ and $E$ ) percent ingestion; $(C$ and $F)$ PI.

ence to collagen gels (Fig. 10). There was no difference in the binding of ligand-coated $\mathrm{E}$ to monocytes adherent to the different substrates (data not shown).

Compared to glass-adherent monocytes, monocytes adherent to fibronectin and vitronectin ingested $34 \%$ and $46 \%$ more EIgG, respectively (Fig. 10). Adherence of monocytes to collagen had no effect on FcR-mediated ingestion, whereas monocytes adherent to collagen gels ingested twice as many EIgG as

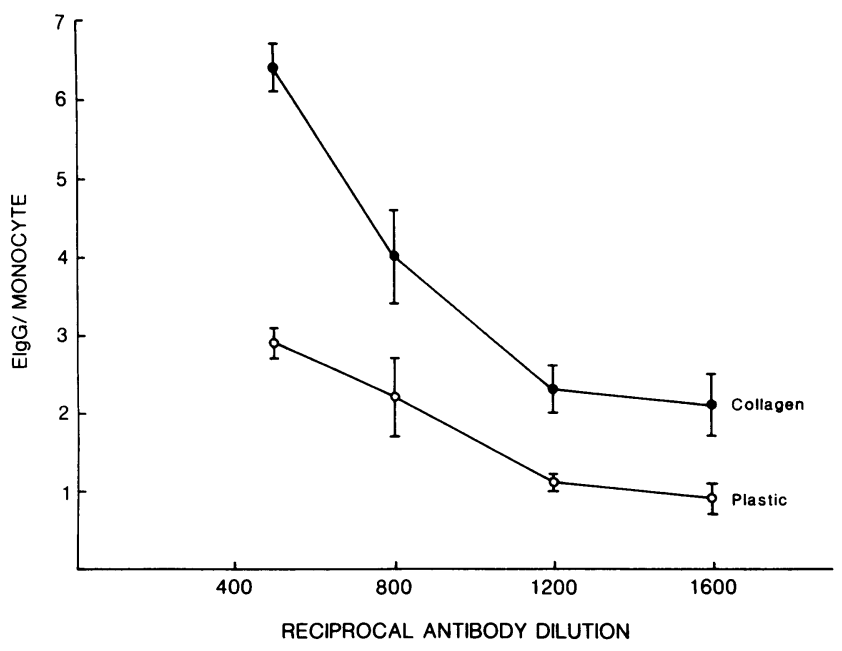

Figure 9. Phagocytosis of ${ }^{51} \mathrm{Cr}$-labeled EIgG. ${ }^{51} \mathrm{Cr}$-labeled EIgG were prepared with varying concentrations of IgG anti-E and aliquots of 2 $\times 10^{7} \mathrm{EIgG}$ were added to monolayers of collagen- and plastic-adherent monocytes in triplicate. Phagocytosis was then quantified after 1 $\mathrm{h}$ at $37^{\circ} \mathrm{C}$. Results are presented as the mean $\pm \operatorname{SEM}(n=3)$ of the number of EIgG ingested per monocyte. glass-adherent monocytes (Fig. 10). Also, under the conditions of assay, monocytes adherent to collagen gels ingested greater numbers of EIgG than monocytes adherent to either fibronectin or vitronectin.

Effect of adherence of monocytes to collagen gels on the respiratory burst. Finally, we sought to determine whether adherence of monocytes to collagen gels had a regulatory effect on the generation of the respiratory burst. Monocytes were adhered to plastic or to collagen gels, and $\mathrm{O}_{2}^{-}$production quantified. The substrate to which monocytes were adhered did not effect the production of $\mathrm{O}_{2}^{-}$when monocytes were incubated with either a particulate (opsonized zymosan) or a soluble (PMA) stimulus (Table I). In addition, no difference in $\mathrm{O}_{2}^{-}$release by plastic- or collagen-adherent monocytes was observed with resting cells. Thus, generation of the respiratory burst was not modified by adherence of monocytes to collagen gels.

\section{Discussion}

We quantified and compared the phagocytic and bactericidal activity of collagen-adherent monocytes vs. plastic-adherent monocytes and 7-d adherently cultured monocyte-derived M $\phi$. All three cell preparations phagocytosed serum opsonized bacteria in a time-dependent manner. However, both the rate of phagocytosis and the total number of opsonized bacteria ingested by collagen-adherent monocytes was greater than that of plastic-adherent monocytes. Collagen-adherent monocytes ingested 2.5-12-fold more microorganisms than plastic-adherent monocytes after $30 \mathrm{~min}$ of incubation. The numbers of $E$. coli and $S$. aureus ingested by collagen-adherent monocytes was equal to or greater than the number of organisms ingested by 7-d cultured $\mathrm{M} \phi$. Adherence of monocytes to collagen did 


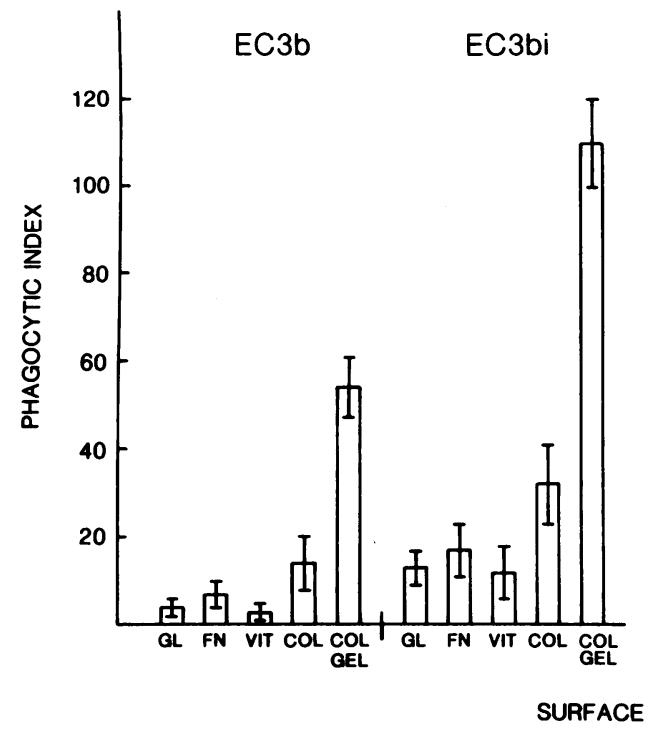

not abrogate the requirement for serum opsonization; opsonization of bacteria via the alternate $C$ pathway was necessary and sufficient for optimum phagocytosis. Thus, adherence of monocytes to collagen gels can significantly increase the phagocytic capacity of monocytes without the need for longterm culture and differentiation into $\mathbf{M} \phi$.

Although both collagen- and plastic-adherent monocytes were bactericidal for $E$. coli and $S$. aureus, more bacteria were killed by collagen-adherent monocytes by virtue of their enhanced phagocytic capacity. In contrast, cultured $\mathbf{M} \phi$ only were bacteriostatic. Thus, collagen-adherent monocytes have the same phagocytic capacity as cultured $\mathbf{M} \phi$, but unlike cultured $\mathbf{M} \phi$, these cells retained their bactericidal activity. The loss of bactericidal activity by cultured $\mathbf{M} \phi$ is consistent with previous reports which demonstrated a loss of antimicrobial activity against viral $(43)$, fungal $(44,45)$, bacterial $(46-48)$, and protozoan $(49,50)$ intracellular pathogens by monocytes cultured in vitro. The loss of antimicrobial activity by cultured M $\phi$ parallels the loss during culture of the enzyme myeloperoxidase (45), and the decline in the ability of cultured $\mathbf{M} \phi$ to be stimulated to release $\mathrm{O}_{2}^{-}(45,51), \mathrm{H}_{2} \mathrm{O}_{2}(45,49)$, and $\cdot \mathrm{OH}(45)$, and again emphasizes the importance of the respiratory burst in phagocyte antimicrobial activity.

Table I. Superoxide Anion Generation by Collagen-vs. Plastic-adherent Monocytes

\begin{tabular}{lccc}
\hline & \multicolumn{3}{c}{$\mathrm{O}_{2}^{-}$} \\
\cline { 2 - 4 } Substrate & Resting cells & $\begin{array}{c}\text { Opsonized } \\
\text { zymosan }\end{array}$ & PMA \\
\hline & & $n m o l / 10^{5}$ monocytes per $h$ \\
Plastic & $1.4 \pm 0.4(10)$ & $5.0 \pm 1.1(5)$ & $3.9 \pm 0.3(5)$ \\
Collagen & $1.5 \pm 0.4(10)$ & $5.5 \pm 0.8(5)$ & $4.1 \pm 0.2(5)$ \\
\hline
\end{tabular}

Adherent monocytes were incubated with opsonized zymosan (2 $\left.\times 10^{7} / \mathrm{ml}\right)$ or PMA $(100 \mu \mathrm{g} / \mathrm{ml})$ for $1 \mathrm{~h}$ at $37^{\circ} \mathrm{C}$, and superoxide anion production was quantified by the reduction of cytochrome $c$. Values are given as mean $\pm \operatorname{SEM}(n)$.
ElgG

Figure 10. Phagocytosis of EC3b(i) and EIgG by monocytes adherent to various substrates. Monocytes were adhered to glass coverslips $(G L)$ or to coverslips coated with fibronectin $(F N)$, vitronectin $(V I T)$, collagen $(C O L)$, and collagen gels (COL GEL). Ligandcoated $\mathrm{E}\left(2 \times 10^{7}\right)$ were added to the monolayers and phagocytosis was quantified after $1 \mathrm{~h}$ at $37^{\circ} \mathrm{C}$. Results are presented as the mean $\pm \operatorname{SEM}(n=5)$ of the phagocytic indices (the number of $E$ ingested per 100 monocytes).
Optimum killing of $E$. coli but not killing of $S$. aureus by collagen- and plastic-adherent monocytes required the presence of extracellular serum, and significant killing of $E$. coli occurred in the absence of extracellular serum. These results differ from the experiments of Leijh et al. (39), who reported that monocytes absolutely required extracellular serum to kill these two microorganisms. No bactericidal activity was evident in the absence of extracellular serum (39). The reason(s) for the discrepancy between our results and the previous studies are unclear. One possible explanation is that the specific strains of $E$. coli and $S$. aureus used in these and the previous experiments have different requirements for intracellular killing. This is unlikely, since all strains of these species are probably killed by toxic oxygen metabolites. One important difference between the two studies is that Leijh et al. (39) studied the bactericidal activity of monocytes in suspension, whereas we studied the bactericidal activity of adherent monocytes. Adherence may, therefore, abrogate the requirement for extracellular serum. Since phagocytes in vivo are adherent to biological surfaces except when in the peripheral circulation, these data may more accurately reflect the in vivo situation.

The mechanism of enhanced phagocytosis of opsonized bacteria by collagen-adherent monocytes appeared to be through regulation of $\mathrm{CR}$ and FcR function. Adherence of monocytes to collagen gels effected an immediate activation of both $\mathrm{CR}_{1}$ and $\mathrm{CR}_{3}$ for phagocytosis, and FcR-mediated phagocytosis was enhanced two-fold. Activation of monocyte $\mathrm{CR}$ for phagocytosis and enhancement of FcR function was maintained during $24-48 \mathrm{~h}$ of culture on collagen gels. These results confirm the observations of Kaplan and Gaudernack (27) that monocytes cultured on collagen gels activated their CR for phagocytosis after $48 \mathrm{~h}$ of culture; culture times earlier than 48 $\mathrm{h}$ were not examined. In contrast to culture on collagen gels, culture of monocytes on glass coverslips results in down regulation of CR expression as we reported previously (22).

Previous studies of the effect of extracellular matrix proteins on monocyte/M $\phi$ receptor function have found that differentiation in vitro is required for activation of CR for phagocytosis. Monocytes required $3 \mathrm{~d}$ of culture in suspension in vitro before adherence of cells to fibronectin (30) or laminin 
(31) activated CR for phagocytosis. Vitronectin, a 165-kD extracellular matrix protein, was reported to enhance FcR-mediated phagocytosis of freshly isolated and adherent monocytes, but did not activate CR for phagocytosis (33), a finding confirmed in the present report. In addition, adherence of monocytes to collagen gels increased FcR-mediated phagocytosis to a greater extent than adherence to vitronectin or fibronectin. Since the extracellular matrix contains a mixture of these, and other proteins, FcR-mediated phagocytosis may be significantly upregulated at sites of inflammation.

In contrast to the results obtained with monocytes, preliminary experiments have indicated that adherence of PMN to collagen gels does not increase the ingestion of opsonized bacteria, activate CR for phagocytosis, or increase FcR-mediated phagocytosis (data not shown). Differential regulation of the phagocytic capacity of monocyte and PMN CR and FcR also has been observed upon stimulation with PMA $(23,25)$ or soluble fibronectin $(28,29)$. Thus, PMA activated PMN CR for phagocytosis (25), but not monocyte CR (23). Likewise, it has been reported that monocytes incubated in suspension with soluble fibronectin were activated to ingest EC $3 \mathrm{~b}(\mathrm{i})$, and FcR-mediated phagocytosis was enhanced (28). However, soluble fibronectin activated PMN CR for phagocytosis only after pretreatment of the cells with a chemotactic factor such as FMLP or C5a (29). Soluble fibronectin enhanced FcR-mediated phagocytosis either after pretreatment of the cells with chemotactic factors (29), or in the presence of catalase (52).

Although adherence of monocytes to collagen gels had a profound effect upon phagocytosis, there was no apparent regulatory effect on the respiratory burst. $\mathrm{O}_{2}^{-}$release by plasticand collagen-adherent monocytes was equivalent in response to PMA and to opsonized zymosan. Adherence of monocytes to collagen vs. plastic also did not effect the amount of $\mathrm{O}_{2}^{-}$ released by unstimulated cells.

Overall, the data presented suggest that in vivo emigration of monocytes from the peripheral circulation into extravascular sites rich in extracellular matrix proteins may rapidly regulate the ability of monocytes responding to an inflammatory stimulus to phagocytose and kill pathogenic microorganisms. Although current dogma would suggest otherwise $(53,54)$, it remains to be determined whether monocytes adherent to collagen might phagocytose and kill microorganisms coated only with $\mathrm{C} 3 \mathrm{~b}(\mathrm{i})$. This possibility currently is under investigation.

The mechanism(s) by which adherence of monocytes to collagen gels activates CR for phagocytosis is unknown. Several potential mechanisms include increasing the number of cell surface receptors, changing the topology of the receptors, or effecting linkage of the receptors to the cellular cytoskeleton. Several studies suggest that increasing the number of CR is not sufficient to activate them for phagocytosis. Thus, treatment of human PMN with PMA (25) or the chemotactic peptide FMLP (55-57) increased the number of cell surface CR, but only treatment with PMA lead to activation of CR for phagocytosis (25). In fact, although FMLP caused an increase in CR number, ligand binding was not increased (57). In addition, PMA, but not FMLP, caused aggregation of PMN CR into distinct clusters on the cell surface, suggesting that clustering is important for enhanced receptor activity (57). However, fibronectin does not increase CR number $(28,58)$ or effect its cell surface distribution (58) on human $\mathrm{M} \phi$, but still activates $\mathrm{CR}$ for phagocytosis. Thus, neither an increase in $\mathrm{CR}$ number nor a change in their topology is necessarily sufficient to lead to activation for phagocytosis.

The ability of extracellular matrix proteins to enhance ingestion of opsonized particles by monocyte/M $\phi(59,60)$ does appear to be dependent on recognition of Arg-Gly-Asp (RGD) sequences within the matrix proteins. The RGD sequence is present in four different locations in the $\alpha 2$ chain and two locations in the $\alpha 1$ chain of the triple-helical region of type I collagen (61). Thus, recognition of one or more of these RGD sequences by specific receptors on monocytes may be required for enhanced CR and/or FcR function. The human osteosarcoma cell line, MG-63 possesses receptors that recognize RGD sequences in the triple helix conformation of type I collagen, but not in heat-denatured collagen, fibronectin, or vitronectin (62). Such receptors have not yet been identified on human monocytes.

Alternatively, monocyte collagen receptors that do not recognize the RGD sequence in collagen may be involved in regulation of receptor function. The "very late antigens" (VLA) are a receptor family of cell surface glycoproteins that promote cell-matrix adhesion, and belong to the integrin family of adhesion molecules (63). Of the six VLA molecules that have been described, VLA-2 has been shown to be specific for collagen, and VLA-3 has been shown to be specific for collagen, laminin, and fibronectin $(64,65)$. Of these, low amounts of only VLA-2 have been detected on human monocytes using $\alpha$-chain specific mAbs. No VLA-2 has been found on human neutrophils (66). Although VLA-2 promotes adhesion to collagen, it does not recognize collagen within the RGD sequence (64). Studies are underway to determine if the regulation of CR and $\mathrm{FcR}$ function on collagen-adherent monocytes is via VLA-2, a type I collagen receptor that recognizes the RGD sequence within collagen, or both.

\section{Acknowledgments}

The authors wish to thank Drs. W. Bullock and G. Deepe for critical review of the manuscript.

This work was supported by National Institutes of Health grant AI-23985.

\section{References}

1. Winkelstein, J. A. 1973. Opsonins: their function, identity, and clinical significance. J. Pediatr. 82:747-753.

2. Horwitz, M. A. 1980. The roles of Fc and C3 receptors in the phagocytosis and killing of bacteria by human phagocytes. J. Reticuloendothel. Soc. 28:17s-26s.

3. Fearon, D. T., and W. W. Wong. 1983. Complement ligand-receptor interactions that mediate biological responses. Annu. Rev. Immunol. 1:243-271.

4. Newman, S. L., and L. K. Mikus. 1985. Deposition of C3b and iC $3 b$ onto particulate activators of the human complement system. Quantitation with monoclonal antibodies to human C3. J. Exp. Med. 161:1414-1431.

5. Brown, E. J., K. A. Joiner, T. A. Gaither, C. H. Hammer, and M. M. Frank. 1983. The interaction of $\mathrm{C} 3 \mathrm{~b}$ bound to pneumococci with factor $\mathrm{H}(\beta 1 \mathrm{H}$ globulin), factor $\mathrm{I}(\mathrm{C} 3 \mathrm{~b} / \mathrm{C} 4 \mathrm{~b}$ inactivator), and properdin factor B of the human complement system. J. Immunol. 131:409-415.

6. Hostetter, M. K. 1986. Serotypic variation among virulent pneumococci in deposition and degradation of covalently bound C $3 \mathrm{~b}$ : 
implications for phagocytosis and antibody production. J. Infect. Dis. 153:682-693.

7. Verbrugh, H. A., P. K. Peterson, B. T. Nguyen, S. P. Sission, and Y. Kim. 1982. Opsonization of encapsulated Staphylococcus aureus: the role of specific antibody and complement. J. Immunol. 129:16811687.

8. Grossman, N., K. A. Joiner, M. M. Frank, and L. Leive. 1986. C3b binding, but not its breakdown, is affected by the structure of the O-antigen polysaccharide in lipopolysaccharide from Salmonellae. $J$. Immunol. 136:2208-2215.

9. Weis, J. J., S. K. Law, R. P. Levine, and P. P. Cleary. 1985. Resistance to phagocytosis by group A streptococci: failure of deposited complement opsonins to interact with cellular receptors. J. Immunol. 134:500-505.

10. Gordon, D. L., J. Rice, J. J. Finlay-Jones, P. J. McDonald, and M. K. Hostetter. 1988. Analysis of C3 deposition and degradation on bacterial surfaces after opsonization. J. Infect. Dis. 157:697-704.

11. Fearon, D. T. 1980. Identification of the membrane glycoprotein that is the $\mathrm{C} 3 \mathrm{~b}$ receptor of the human erythrocyte, polymorphonuclear leukocyte, B lymphocyte, and monocyte. J. Exp. Med. 152:20-30.

12. Beller, D. I., T. A. Springer, and R. D. Schreiber. 1982. AntiMac-1 selectively inhibits the mouse and human type three complement receptor. J. Exp. Med. 156:1000-1009.

13. Wright, S. D., P. E. Rao, W. C. Van Voorhis, L. S. Craigmyle, K. Iida, M. A. Talle, E. F. Westberg, G. Goldstein, and S. C. Silverstein. 1983. Identification of the $\mathrm{C} 3 \mathrm{bi}$ receptor of human monocytes and macrophages by using monoclonal antibodies. Proc. Natl. Acad. Sci. USA. 80:5699-5703.

14. Anderson, C. L., and R. J. Looney. 1986. Human leukocyte IgG Fc receptors. Immunol. Today. 7:264-266.

15. Colton, H. R. 1985. Biology of disease: molecular basis of complement deficiency syndromes. Lab. Invest. 52:468-474.

16. Rosen, F. S., and C. A. Janeway. 1966. The gammaglobulins. III. The antibody deficiency syndromes. $N$. Engl. J. Med. 275:709715.

17. Ross, G. D., R. A. Thompson, M. J. Walport, T. A. Springer, J. V. Watson, R. H. R. Ward, J. Lida, S. L. Newman, R. A. Harrison, and P. J. Lachmann. 1985. Characterization of patients with an increased susceptibility to bacterial infections and a genetic deficiency of leukocyte membrane complement receptor type three and the related membrane antigen LFA-1. Blood. 66:882-890.

18. Mantovani, B. 1975. Different roles of IgG and complement receptors in phagocytosis by polymorphonuclear leukocytes. $\mathrm{J}$. Immunol. 115:15-17.

19. Scribner, D. J., and D. Fahrney. 1976. Neutrophil receptors for IgG and complement: their roles in the attachment and ingestion phases of phagocytosis. J. Immunol. 116:892-897.

20. Newman, S. L., and R. B. Johnston, Jr. 1979. Role of binding through $\mathrm{C} 3 \mathrm{~b}$ and IgG in polymorphonuclear neutrophil function. Studies with trypsin-generated C3b. J. Immunol. 123:1839-1846.

21. Ehlenberger, A. G., and V. Nussenzweig. 1977. The role of membrane receptors for $\mathrm{C} 3 \mathrm{~b}$ and $\mathrm{C} 3 \mathrm{~d}$ in phagocytosis. J. Exp. Med. 145:357-371.

22. Newman, S. L., R. A. Musson, and P. M. Henson. 1980. Development of functional complement receptors during in vitro maturation of human monocytes into macrophages. J. Immunol. 125:22362244.

23. Wright, S. D., and S. C. Silverstein. 1982. Tumor-promoting phorbol esters stimulate $\mathrm{C} 3 \mathrm{~b}$ and $\mathrm{C} 3 \mathrm{~b}^{\prime}$ receptor-mediated phagocytosis in cultured human monocytes. J. Exp. Med. 156:1149-1164.

24. Newman, S. L., J. E. Devery-Pocius, G. D. Ross, and P. M. Henson. 1984. Phagocytosis by human monocyte-derived macrophages. Independent function of receptors for $\mathrm{C} 3 \mathrm{~b}\left(\mathrm{CR}_{1}\right)$ and $\mathrm{iC} 3 \mathrm{~b}$ ( $\left.\mathrm{CR}_{3}\right)$. Complement. 1:213-227.

25. Wright, S. D., and B. C. Meyer. 1986. Phorbol esters cause sequential activation and deactivation of complement receptors on polymorphonuclear leukocytes. J. Immunol. 136:1759-1764.

26. Griffin, F. M., Jr., and P. J. Mullinax. 1985. Effects of differentiation in vivo and of lymphokine treatment in vitro on the mobility of $\mathrm{C} 3$ receptors of human and mouse mononuclear phagocytes. J. Immunol. 135:3394-3397.

27. Kaplan, G., and G. Gaudernack. 1982. In vitro differentiation of human monocytes. Differences in monocyte phenotypes induced by cultivation on glass or on collagen. J. Exp. Med. 156:1101-1114.

28. Pommier, C. G., S. Inada, L. F. Fries, T. Takahashi, M. M. Frank, and E. J. Brown. 1983. Plasma fibronectin enhances phagocytosis of opsonized particles by human peripheral blood monocytes. $J$. Exp. Med. 157:1844-1854.

29. Pommier, C. G., J. O'Shea, T. Chused, K. Yancey, M. M. Frank, T. Takahashi, and E. J. Brown. 1984. Studies on the fibronectin receptors of human peripheral blood leukocytes. Morphologic and functional characterization. J. Exp. Med. 159:137-151.

30. Wright, S. D., L. S. Craigmyle, and S. C. Silverstein. 1983. Fibronectin and serum amyloid $\mathrm{P}$ component stimulate $\mathrm{C} 3 \mathrm{~b}$ - and C3bi-mediated phagocytosis in cultured human monocytes. J. Exp. Med. 158:1338-1343.

31. Bohnsack, J. F., H. K. Kleinman, T. Takahashi, J. J. O'shea, and E. J. Brown. 1985. Connective tissue proteins and phagocytic cell function. Laminin enhances complement and Fc-mediated phagocytosis by cultured human macrophages. J. Exp. Med. 161:912-923.

32. Gresham, H. D., L. T. Clement, J. E. Lehmeyer, F. M. Griffin, Jr., and J. E. Volanakis. 1986. Stimulation of human neutrophil Fc receptor-mediated phagocytosis by a low molecular weight cytokine. $J$. Immunol. 137:868-875.

33. Parker, C. J., R. N. Frame, and M. R. Elstad. 1988. Vitronectin (S protein) augments the functional activity of monocyte receptors for IgG and complement C3b. Blood. 71:86-93.

34. Dayer, J-M., S. Ricard-Blum, M-T. Kaufmann, and D. Herbage. 1986. Type IX collagen is a potent inducer of $P E_{2}$ and interleukin 1 production by human monocyte macrophages. FEBS (Fed. Eur. Biochem. Soc.) Lett. 198:208-212.

35. Eierman, D. F., C. E. Johnson, and J. S. Haskill. 1989. Human monocyte inflammatory mediator gene expression is selectively regulated by adherence substrates. J. Immunol. 142:1970-1976.

36. Kaplan, G. 1983. In-vitro differentiation of human monocytes. Monocytes cultured on glass are cytotoxic to tumor cells but monocytes cultured on collagen are not. J. Exp. Med. 157:2061-2072.

37. Fine, D. P., S. R. Marney, Jr., D. G. Colley, J. S. Sergent, and R. M. Des Prez. 1972. C3 shunt activation in human serum chelated with EGTA. J. Immunol. 109:807-809.

38. Bevilacqua, M. P., D. Amrani, M. W. Mosesson, and C. Bianco. 1981. Receptors for cold-insoluble globulin (plasma fibronectin) on human monocytes. J. Exp. Med. 153:42-60.

39. Leijh, P. C. J., M. T. van den Barselaar, T. L. van Zwet, M. R. Daha, and R. van Furth. 1979. Requirement of extracellular complement and immunoglobulin for intracellular killing of micro-organisms by human monocytes. J. Clin. Invest. 63:772-784.

40. Solberg, C. O. 1975. Influence of therapeutic concentrations of phenylbutazone on granulocyte function. Acta Pathol. Microbiol. Scand. Sect. B. 83:100-102.

41. Johnston, R. B., Jr. 1981. Secretion of superoxide anion. In Methods for Studying Mononuclear Phagocytes. D. O. Adams, P. J. Edelson, and H. Koren, editors. Academic Press, Inc., New York. 489-497.

42. Elsdale, T., and J. Bard. 1972. Collagen substrata for studies on cell behavior. J. Cell Biol. 54:626-637.

43. Daniels, C. A., E. S. Kleinerman, and R. Snyderman. 1978. Abortive and productive infections of human mononuclear phagocytes by type 1 herpes simplex. Am. J. Pathol. 91:119-129.

44. Diamond, R. D., and J. E. Bennett. 1973. Growth of Cryptococcus neoformans within human macrophages in vitro. Infect. Immun. 7:231-236. 
45. Sasada, M., A. Kubo, T. Nishimura, T. Kakita, T. Moriguchi, K. Yamamoto, and H. Uchino. 1987. Candidacidal activity of monocyte-derived human macrophages: relationship between candida killing and oxygen radical generation by human macrophages. J. Leukocyte Biol. 41:289-294.

46. Horwitz, M. A., and S. C. Silverstein. 1981. Activated human monocytes inhibit the intracellular multiplication of Legionnaires' disease bacteria. J. Exp. Med. 154:1618-1635.

47. Czuprynski, C. J., P. A. Campbell, and P. M. Henson. 1983. Killing of Listeria monocytogenes by human neutrophils and monocytes, but not by monocyte-derived macrophages. J. Reticuloendothel. Soc. 34:29-44.

48. Rothermel, C. D., B. Y. Rubin, E. A. Jaffe, and H. W. Murray. 1986. Oxygen-independent inhibition of intracellular Chlamydia psittaci growth by human monocytes and interferon- $\gamma$-activated macrophages. J. Immunol. 137:689-692.

49. Murray, H. W., and D. M. Cartelli. 1983. Killing of intracellular Leishmania donovani by human mononuclear phagocytes: evidence for oxygen-dependent and -independent leishmanicidal activity. J. Clin. Invest. 72:32-44.

50. Murray, H. W., B. Y. Rubin, S. M. Carriero, A. M. Harris, and E. A. Jaffe. 1985. Human mononuclear phagocyte antiprotozoal mechanisms: oxygen-dependent vs oxygen-independent activity against intracellular Toxoplasma gondii. J. Immunol. 134:1982-1988.

51. Pabst, M. J., H. B. Hedegaard, and R. B. Johnston, Jr. 1982. Cultured monocytes require exposure to bacterial products to maintain an optimal oxygen radical response. J. Immunol. 128:123-128.

52. Gresham, H. D., J. L. Goodwin, P. M. Allen, D. C. Anderson, and $\mathrm{E}$. J. Brown. 1989. A novel member of the integrin family mediates Arg-Gly-Asp-stimulated neutrophil phagocytosis. J. Cell Biol. 108:1935-1943.

53. Wright, S. D., and S. C. Silverstein. 1983. Receptors for C3b and C3bi promote phagocytosis but not the release of toxic oxygen from human phagocytes. J. Exp. Med. 158:2016-2023.

54. Yamomoto, K., and R. B. Johnston, Jr. 1984. Dissociation of phagocytosis from stimulation of the oxidative metabolic burst in macrophages. J. Exp. Med. 159:405-416.

55. Berger, M., J. O'Shea, A. S. Cross, T. M. Folks, T. M. Chused, E. J. Brown, and M. M. Frank. 1984. Human neutrophils increase expression of $\mathrm{C} 3 \mathrm{bi}$ as well as $\mathrm{C} 3 \mathrm{~b}$ receptors upon activation. J. Clin. Invest. 74:1566-1571.
56. O'Shea, J., E. J. Brown, B. E. Seligman, J. A. Metcalf, M. M. Frank, and J. I. Gallin. 1985. Evidence for distinct intracellular pools of receptors for $\mathrm{C} 3 \mathrm{~b}$ and $\mathrm{C} 3 \mathrm{bi}$ in human neutrophils. J. Immunol. 134:2580-2587.

57. Detmers, P. A., S. D. Wright, E. Olsen, B. Kimball, and Z. A. Cohn. 1987. Aggregation of complement receptors on human neutrophils in the absence of ligand. J. Cell Biol. 105:1137-1145.

58. Wright, S. D., M. R. Licht, L. S. Craigmyle, and S. C. Silverstein. 1984. Communication between receptors for different ligands on a single cell: ligation of fibronectin receptors induces a reversible alteration in the function of complement receptors on cultured human monocytes. J. Cell Biol. 99:336-339.

59. Wright, S. D., and B. C. Meyer. 1985. Fibronectin receptor of human macrophages recognizes the sequence arg-gly-asp-ser. J. Exp. Med. 162:762-767.

60. Brown, E. J., and J. L. Goodwin. 1988. Fibronectin receptors of phagocytes. Characterization of the arg-gly-asp binding proteins of human monocytes and polymorphonuclear leukocytes. J. Exp. Med. 167:777-793.

61. Bernard, M. P., J. C. Myers, M. L. Chu, F. Ramirez, E. F. Eikenberry, and D. J. Prockop. 1983. Structure of a cDNA for the pro $\alpha 2$ chain of human type I procollagen: Comparison with chick cDNA for pro $\alpha 2(I)$ identifies structurally conserved features of the protein and the gene. Biochemistry. 22:1139-1145.

62. Dedhar, S., E. Ruoslahti, and M. D. Pierschbacher. 1987. A cell surface receptor complex for collagen type I recognizes the arg-gly-asp sequence. J. Cell Biol. 104:585-593.

63. Hemler, M. E. 1988. Adhesive receptors on hematopoietic cells. Immunol. Today. 16:109-113.

64. Wayner, E. A., and W. G. Carter. 1987. Identification of multiple adhesion receptors for collagen and fibronectin in human fibrosarcoma cells possessing unique $\alpha$ and common $\beta$ subunits. J. Cell Biol. 105:1873-1884.

65. Takada, Y., E. A. Wayner, W. G. Carter, and M. E. Hemler. 1988. Extracellular matrix receptors, ECMRII and ECMRI, for collagen and fibronectin correspond to VLA-2 and VLA-3 in the VLA family of heterodimers. J. Cell. Biochem. 37:385-393.

66. Hemler, M. E., C. Huang, and L. Schwarz. 1987. The VLA protein family: characterization of five distinct cell surface heterodimers each with a common 130,000 molecular weight $\beta$ subunit. $J$. Biol. Chem. 262:3300-3309. 